\title{
The Impact of Forest Invasion in the Glades on Birds in Arusha National Park
}

\author{
Masolele MM1*, Kahana LW² and Sylvina TJ ${ }^{3}$ \\ 1Serengeti Biodiversity Programme, Tanzania \\ ${ }^{2}$ College of African Wildlife Management Mweka, Tanzania \\ 3Independent, College of African Wildlife Management Mweka, Tanzania
}

Research Article

Volume 1 Issue 2

Received Date: August 01, 2017

Published Date: August 21, 2017

DOI: $10.23880 /$ jenr-16000108

\begin{abstract}
*Corresponding author: Majaliwa M Masolele, Bachelor Degree in Wildlife
\end{abstract}
Management-College of African Wildlife Management, P.O.BOX 661, Arusha, Tanzania, Tel: +255743227297/+255683211137; E-mail: majaliwa117@gmail.com

\section{Abstract}

This study was aimed at determining how growth of forest into man-made and natural glades affects bird species diversity, richness and evenness, and feeding guild composition in Arusha National Park, Tanzania. The fixed belt transect plot was used to survey bird species during the wet season. Fifty-eight bird species among 29 Families from 11 Orders were recorded. Passeriformes was the dominant Order for both glade types. The Shannon-Wiener Diversity Index was highest for man-made glades, as compared to that of natural glades $\left(H^{\prime}=3.677\right.$ and $H^{\prime}=3.1$, respectively). Student's t-test analysis of the means of bird diversity in forest transects and corresponding forest-invaded glade transects showed that there was no significant difference in bird species diversity between the two glade types $(t=-3.4208, p=0.07186)$. Manmade glades had a higher species richness than natural glades (Margalef's Richness Index $\mathrm{R}_{1}=8.93$ and $\mathrm{R}_{1}=6.219$, respectively) and this variation was statistically significant (Chi-square: $\chi 2=4.5696, \mathrm{P}=0.033$ ). Also, species evenness was higher in man-made glades than in natural glades (Pielou J=0.8069 and J=0.7627, respectively). The Sorensen Similarity Index analysis showed that bird species communities were similar ( $C C=0.53$ ), with insectivores being most dominant feeding guild for both glade types. Since the variety of bird species for forest-invaded man-made glades was richer and more even than for the natural glades, we conclude that re-clearing of forest invasion for man-made glades should proceed in order to generate these different unique microhabitats that are vital to the conservation of a wide variety of bird species. This is in contrast to not re-clearing forest invasion into man-made glades, where diverse microhabitats would not be generated or available to support increased bird species richness and evenness. Hence, maintenance of these unique microhabitats will promote less decline of bird diversity in Arusha National Park. 


\section{Journal of Ecology \& Natural Resources}

\section{Introduction}

\section{Background}

Global patterns of biodiversity change over both space and time and thus, require integrated ecological and evolutionary perspectives at temporal and broad spatial scales to determine how observational changes for given time-space coordinates $[1,2,3,4]$. There is an unequal distribution of biodiversity on the earth's surface, and understanding the factors that control geographical variations is one of the challenges of ecology [5]. Ecological processes, including temporal and spatial differences in the characteristics of a given ecosystem may contribute to the spatial distribution of species [5]. Currently, there is a huge interest in conserving biological diversity due to the sharp increase of species extinction, as the result of habitat loss, fragmentation, degradation and transformation and climate change [6,7]. A diversity of bird species inhabits a huge variety of habitats on different land masses and in fresh and salt water bodies around the world, including areas at extreme latitudes and land elevations. Some of the smallest nations have many bird fauna [8].

Birds are important components of the world's ecosystems and one of the most conspicuous groups of diverse fauna. Although their distribution ranges from oceans to frozen polar zones, steaming rain forest, barren deserts, land, freshwater bodies, and from the lowest deserts to the highest mountains, birds are certainly more abundant in some places than others $[9,10]$. Understanding the factors responsible for the uneven distribution of bird species richness is a major challenge in ecology [11]. Patterns of bird species diversity are determined by fundamental biogeographic factors, with tropical countries supporting the highest number of species (species richness) especially in South America and Africa. A total of over 10,000 different species of birds worldwide is recognized by Birdlife International, with the highest numbers occupying mainland regions, and the rest on the islands [10]. The information about the distributions of birds are well-known compared to the other taxa, and they are also determined by these fundamental biogeographical factors. This makes birds a useful starting point of mapping broad-scale patterns of species diversity, richness, evenness and endemism $[8,10]$ There is much to argue about as to which factors have been vital in driving global patterns of biological diversity. The variations of conditions experienced in evolutionary time have resulted in the existence of big geographic differences in bird species diversity [8]. Variety (and area) of the diverse habitats present is the most influential cause. Tropical forests are chiefly endowed with a diversity of plant and insect species; and hence, influences high avian diversity in the equatorial regions $[10,2]$. Other major factors that influence avian diversity includes competition, predation, mutualism, disturbance, natural enemies, physical barriers, climatic events and most recently, expanding and pervasive human impacts [10].

Habitat loss and transformations, and climate change being enormous problems for birds [12,13]. Certain sensitive bird species are negatively affected by the eradication of indigenous vegetation, forests, shrub land, or grassland to make way for agriculture, commercial exotic plantations, or development activities, such as human settlement and industrial uses [12]. Draining of wetland areas has caused great loss of water birds such as cranes, geese and ducks. Pollution of air, water, and land inevitably affects bird life [14]. Human disturbance at nesting sites is not tolerated by most species and this often leads to birds deserting their nests with subsequent loss of eggs or chicks [12].

Inadequate community conservation education has led to haphazard farmering practices that has resulted in eradication of birds of prey, cranes, and bustards due to pesticide and herbicide poisoning of carcasses and grains, and bird shooting and trapping [12]. Habitat modifications have the potential to cause changes in the structure and composition of bird communities [11,13]. Insects form the most important part of the diet of many bird species. Also, feeding on snails, beetles or moth larvae that contain insecticide will adversely affect birds to a greater or lesser degree. Depending on the dose and how many affected meals are eaten, insecticides can have a severely debilitating effect on the birds, and even cause death [12].

Forest is defined as the large area of land or ecosystem covered chiefly with large trees and undergrowth [15]. Within forested regions are glades, which are "open, rocky, barren areas with shallow soils that support unique communities of drought-adapted forbs, warmseason grasses, and a specialized fauna" [16]. Glades can either be natural or man-made. Natural glades that occur in some areas are due to local climatic conditions, drainage, and volcanic eruption [16]. Man-made glades occur due to human activities, such as clearing of forest for the purposes of attracting grazers [17]. In most cases, glades have a slanted terrain because they usually occur in the middle of sloped areas with forest cover both above and below. Infrequently, a glade will cover the top of a ridge where the terrain is virtually level [18]. 
Many parts of the world, including Africa, are facing the problem of woody plant intrusion [19]. Woody plant invasion has resulted in the increase of cover of shrubs and trees in some areas, such as glades, plains, savannas and grasslands [20]. Forest invasion in a glade is referred to as woody plant encroachment into a grassland island found in a forest [15]. Woody plants invade the grassland through a process known as bush encroachment. The continuous growth of woody plants is considered a challenge in glades because woody plants alter glade structure [18]. Several studies have suggested factors that contribute to the increase of woody plant encroachment, including grazing intensity by wild herbivores, frequent fire, precipitation, climate change, increase in atmospheric carbon dioxide concentration and soil resources [20,16,21]. Forest invasion into the glades affects birds by altering their habitats and vegetation structure and influence changes in both biotic and abiotic conditions [22,17]. Another scholar suggests that the bird population of glades and their surrounding forest are affected by glade edges that influence both biotic and abiotic conditions [22]. Glade edge zones are hotter, drier and windier due to the absorption of more solar radiations [23]. Glade size and its edge habitat influence variations in distances that these edge effects penetrate into the forest. In turn, this influences the diversity and abundance of birds found in this zone [22].

Arusha National Park (ANAPA) has natural and manmade glades in different, but adjacent habitats [17], with the man-made glades being more highly invaded by woody plants. The contrast of low forest invasion into natural glades and high invasion into man-made glades makes this an ideal site to the impact of forest invasion into man-made and natural glades on bird species diversity, richness and evenness, and feeding guild composition.

\section{Problem Statement and Justification}

Glades are among the important habitats which harbor and support a variety of wildlife species (flora and fauna), They are composed of different species of plants, invertebrates, fish, reptiles, amphibians, mammals and birds with basic habitat requirements, such as food, water and shelter (cover), being available in the area [16. Invading uncharacteristic woody plants are considered a threat to the integrity of the glade $[18,16]$. Plant-bird relations in glades are not well understood and the consequences of glade maintenance efforts are unpredictable [18]. It is with this background the study was conducted. The study discloses the glade conditions and information on bird species diversity, richness and evenness, and feeding guild composition. Furthermore, the study aimed to provide management recommendations about the conservation and maintenance of man-made and natural glades based on the study findings.

\section{Objectives}

\section{Overall Objective}

To determine how growth of forest into man-made and natural glades affects bird species diversity, richness and evenness, and feeding guild composition.

\section{Specific Objectives}

There were two specific objectives:

1) To assess the impact of forest invasion on bird species diversity, richness and evenness and

2) To assess changes in bird feeding guild composition under different levels of forest invasion.

\section{Hypothesis}

There is no difference in bird species diversity, richness and evenness with an increase of forest invasion.

There is no difference in bird foraging guild composition under different levels of forest invasion.

\section{Methodology}

\section{Study Area}

The study was conducted in Arusha National park in northern Tanzania on the eastern slopes of Mount Meru, $25 \mathrm{~km}$ from Mount Kilimanjaro and $35 \mathrm{~km}$ Northeast of Arusha town [24]. The study area is $552 \mathrm{~km}^{2}$ in size with an altitude ranging from 1,500 to 2,800 meters above sea levels (m.a.s.l.) and lies at $03^{\circ} 16^{\prime}$ to $03^{\circ} 20^{\prime} \mathrm{S}$; $36^{\circ} 45^{\prime}$ to $36^{\circ} 53^{\prime}$ E. There are two glade types present in this landscape, man-made and natural glades [17]. The manmade glades are located between 1,400 and 1,800 m.a.s.l. and the natural glades are located between 1,400 and 2,000 m.a.s.l. Glades constitute $4.8 \%$ of the area of the National park [17]. The climate varies with altitude and there are two rainy seasons: the short rains (from November and December), and the long rains (from mid March to late May). However, within the park, rainfall varies from year to year and place to place. In lower, drier areas, it ranges between $600 \mathrm{~mm}$ and $1,300 \mathrm{~mm}$, and at 2,590 m.a.s.l., in the Meru crater between $1,400 \mathrm{~mm}$ and $2,400 \mathrm{~mm}$. The temperature during the hottest season (January and February) rarely exceeds $27^{\circ} \mathrm{C}$ and in the cold season, (June through August) the temperatures are 
lower mid-day and do not drop much below $15^{\circ} \mathrm{C}$ [24]. On the higher parts of Mount Meru, temperatures are lower and frost occurs at night during the cold season. The area has different vegetation, such as evergreen forest, shrubs, bush land, thickets and grassland [24,25].

\section{Materials and Methods}

\section{Reconnaissance Survey and Data Collection}

In order to identify areas for establishing plots for bird surveys and identification, a reconnaissance survey was conducted in the study area. The level of forest invasion into glades were classified into two categories low and high based on total cover and visual estimation [26]. For man-made glades the level of forest invasion were categorized as high and low in natural glades. Sixteen (16) plots each measuring $40 \mathrm{~m}$ long $x 30 \mathrm{~m}$ wide $\left(1,200 \mathrm{~m}^{2}\right)$ were set-up across four man-made and four natural, randomly selected glade areas that had been visually identified as having high and low forest invasion respectively. For each glade area, two plots were established, with one being located within the forest and the other being located in the part of the glade being invaded by forest, starting at the forest-glade edge. The distance apart was $100 \mathrm{~m}$ from one plot to another to avoid double counting [17,27]. Bird species were recorded by slowly walking at a speed of 10 meters per minute, and counting and identifying all individuals seen or heard within the plots with the aid of binoculars and a field guide book $[17,28]$. During the wet season in May, bird surveys were conducted twice a day, in early morning hours from 7:00 to 09:00 and evening hours from 16:00 to $18: 00$ when birds are most active [29]. Observations were not made during mid-day hours because birds tend to hide in cover to avoid the higher temperatures [19]. Plots were surveyed daily for sixteen consecutive days, during each visit; plot surveyed was randomly selected using the random number generated to avoid bias [17]. The direct observation method was used for data collection in sixteen plots surveyed and enabled bird identification and recording of bird activity patterns and other observations made in each glade type. Data for all sixteen plots surveyed were recorded in the data sheet.

Bird species were divided among ten different foraging guild groups, as modified by Zakaria et al.: Carnivores, Frugivores, Granivores, Insectivores, Nectarivores, Omnivores, Carnivore/Insectivores, Frugivores/Insectivo res, Granivores/Insectivores, and Carnivores/Piscivores/I nsectivores [30].

Source: Kahana et al. 2013

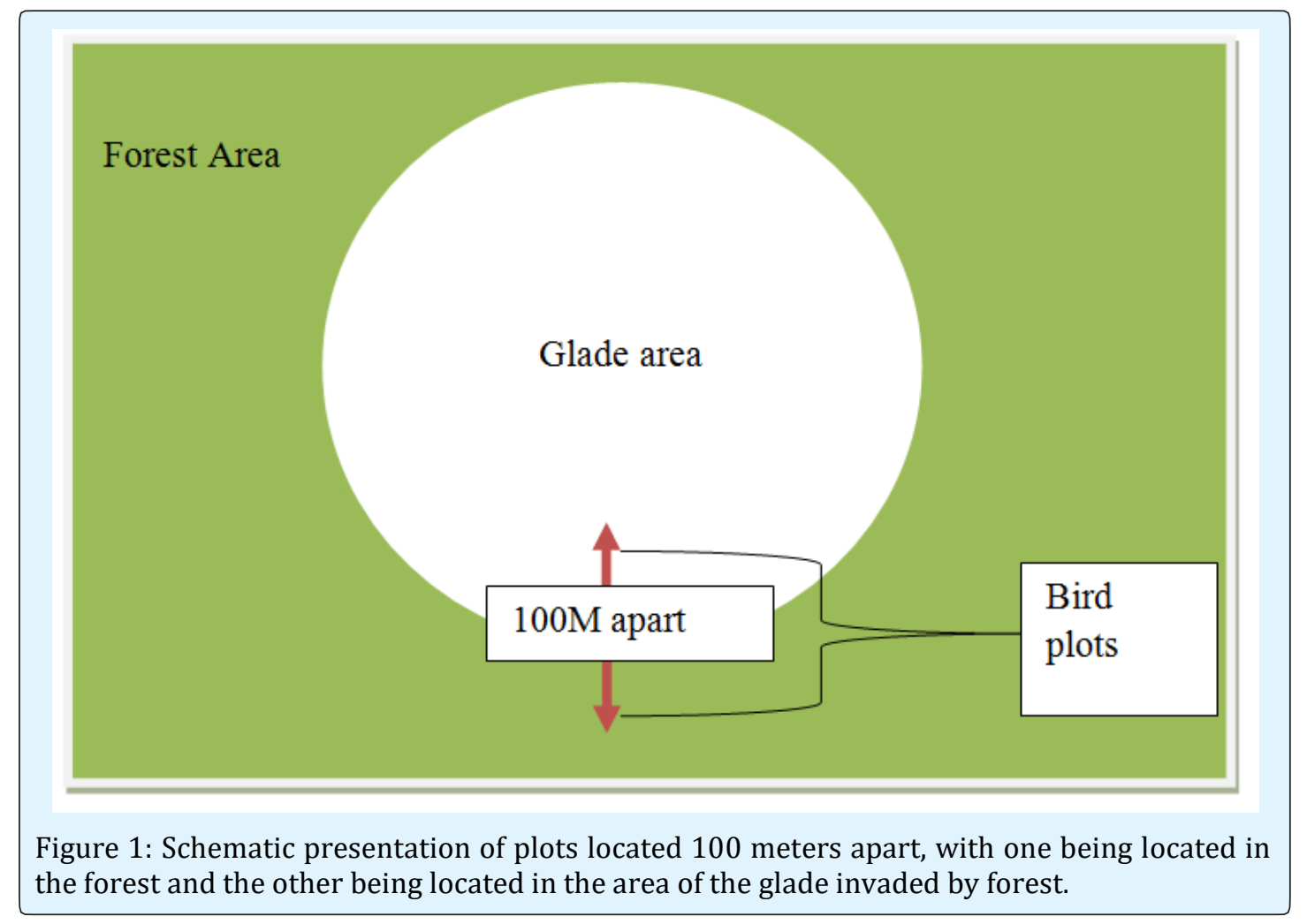




\section{Data Analysis}

Data were analyzed using Shannon-Wiener index, Sorensen similarity index and descriptive and inferential statistics. Shannon-Wiener Index $\left(\mathrm{H}^{\prime}\right)$ was used to measure species diversity in each of the eight glade areas [31]. The Sorensen similarity index was used to measure similarities in bird species composition between manmade and natural glade areas [32]. The means of the forest transect and its corresponding forest-invaded glade transects was used to test the significance differences in bird species diversity between man-made and natural glades using Student's t-test [33,34]. Chi-square test was used to test significant differences in bird species richness between man-made and natural glades [35,36]. All inferential statistics were performed under two tailed test with significant level at $\mathrm{P} \leq 0.05$ [37].

\section{Results}

Fifty-eight bird species were recorded (see Table 1). Out of these, 106 individual species were recorded in the forest around glades and the forest invading the glades for natural glades and 218 in the man-made glade, belonging to 11 Orders distributed among 29 Families. Common bulbuls were the indicators of the forest-glade edge of both glade types. The woody plant species (trees and shrubs) invading the glades were also recorded, although the data were not analyzed.

\begin{tabular}{|c|c|c|c|}
\hline Family name & Common name of bird species & $\begin{array}{c}\text { Number of individual species } \\
\text { in man-made glades }\end{array}$ & $\begin{array}{c}\text { Number of individual } \\
\text { species in natural glades }\end{array}$ \\
\hline \multirow[t]{5}{*}{ Accipitridae } & Eastern Chanting-Goshawk & & 1 \\
\hline & Augur Buzzard & 2 & 1 \\
\hline & Steppe Eagle & & 1 \\
\hline & Long - crested Eagle & 2 & \\
\hline & Pallid Harrier & 1 & \\
\hline Alcedinidae & Brown- hooded Kingfisher & & 1 \\
\hline \multirow{2}{*}{ Anatidae } & Egyptian Goose & 4 & \\
\hline & Spur -winged Goose & 2 & \\
\hline \multirow[t]{3}{*}{ Ardeidae } & Hammerkop & 1 & \\
\hline & Black- headed Heron & 5 & 2 \\
\hline & Cattle Egret & 4 & \\
\hline \multirow[t]{2}{*}{ Bucerotidae } & Crowned Hornbill & 4 & \\
\hline & Silvery -cheeked Hornbill & & 4 \\
\hline \multirow{2}{*}{ Buphagidae } & Yellow -billed Oxpecker & 5 & 3 \\
\hline & Red- billed Oxpecker & 3 & \\
\hline \multirow[t]{3}{*}{ Capitoniidae } & Spot- flanked Barbet & 2 & 1 \\
\hline & White -eared barbet & 2 & \\
\hline & Brown- breasted Barbet & 3 & \\
\hline Charadriidae & Blacksmith Lapwing & 1 & \\
\hline \multirow[t]{2}{*}{ Cisticolidae } & Tawny -flanked Prinia & 4 & 2 \\
\hline & Grey- backed Camaroptera & 4 & 3 \\
\hline Coliidae & Speckled Mousebird & 6 & 4 \\
\hline \multirow[t]{4}{*}{ Columbidae } & African Mourning Dove & 4 & 6 \\
\hline & Dusky Turtle Dove & & 2 \\
\hline & Emerald- spotted Wood- Dove & 3 & \\
\hline & Eastern Bronze- naped Pigeon & 2 & \\
\hline \multirow[t]{2}{*}{ Cuculidae } & White- browed Coucal & 2 & 2 \\
\hline & Red -chested Cuckoo & 2 & \\
\hline \multirow[t]{4}{*}{ Emberizidae } & Red -faced Crimsonwing & 8 & \\
\hline & Black- and -white Mannikin & 9 & \\
\hline & Common Waxbill & 8 & \\
\hline & $\begin{array}{c}\text { Cinnamon-breasted Rock } \\
\text { Bunting }\end{array}$ & & 1 \\
\hline
\end{tabular}




\section{Journal of Ecology \& Natural Resources}

\begin{tabular}{|c|c|c|c|}
\hline & Bronze manikin & 13 & 6 \\
\hline Hirundinidae & Black Saw-wing & 8 & 6 \\
\hline & Plain Martin & 8 & 8 \\
\hline Laniidae & Common Fiscal shrike & 7 & 5 \\
\hline Malaconotidae & Tropical Boubou & 6 & 2 \\
\hline Meropidae & Slate - coloured Boubou & 3 & 2 \\
\hline Muscicapidae & Little Bee-eater & 4 & 2 \\
\hline & White- eyed Slaty Flycatcher & 3 & 2 \\
\hline & African Dusky Flycatcher & 4 & \\
\hline & African Paradise -flycatcher & 4 & 6 \\
\hline Musophagidae & Hartlaub's Turaco & 3 & 8 \\
\hline Nectariniidae & Scarlet -chested Sunbird & 4 & 14 \\
\hline Numididae & Variable Sunbird & 4 & 2 \\
\hline Passeridae & Helmeted Guineafowl & & \\
\hline Pcynonotidae & Chestnut Sparrow & 17 & 4 \\
\hline Phasianidae & Common Bulbul & 2 & \\
\hline Platysteiridae & Scaly Francolin & 5 & \\
\hline Ploceidae & Chin-spot Batis & & \\
\hline & Baglafecht Weaver & 10 & \\
\hline & Taveta Golden Weaver & 6 & \\
\hline Pycnonotidae & Spectacled Weaver & 3 & 1 \\
\hline Threskiornithidae & Sacred Ibis & 1 & \\
\hline & Hadada Ibis & 6 & \\
\hline Turdidae & Ruppell's Robin -chat & 2 & \\
\hline
\end{tabular}

Table 1: List of bird species found in man-made and natural glades

\section{Bird species diversity, evenness and similarity in man-made and natural glades}

Bird species diversity, richness and evenness were calculated using PAST 3.06. As shown in Table 2, bird species diversity was highest in man-made glades as compared to natural glade. Student's t-test analysis showed that there was no significant difference in bird species diversity between man-made and natural glades $(t=-3.4208, p=0.07186)$. The bird species evenness was highest in man-made glades (Pielou J=0.8069) and lowest in natural glades (Pielou J=0.7627). The Sorensen similarity index analysis showed similarity in bird species $(\mathrm{CC}=0.53)$ for man-made and natural glades.

\begin{tabular}{|c|c|c|}
\hline Glade type & Shannon Wiener Diversity Index (H') & Evenness (Pielou J) \\
\hline Man-made & 3.677 & 0.8069 \\
\hline Natural & 3.1 & 0.7627 \\
\hline
\end{tabular}

Table 2: Bird species diversity and evenness in man-made and natural glades

\section{Bird species richness in man-made and natural glades}

The total number of bird species recorded in four manmade glades were (49) and (30) in four natural glades in sixteen plots (Figure 2). The Margalef's Richness Index showed that man-made glade had the highest species richness $\left(\mathrm{R}_{1}=8.93\right)$ and lowest in natural glades ( $\mathrm{R}_{1}=6.219$ ). The bird species richness differed significantly between the two glade types (Chi-square: $\chi 2=4.5696, \mathrm{P}=$ 0.033). 


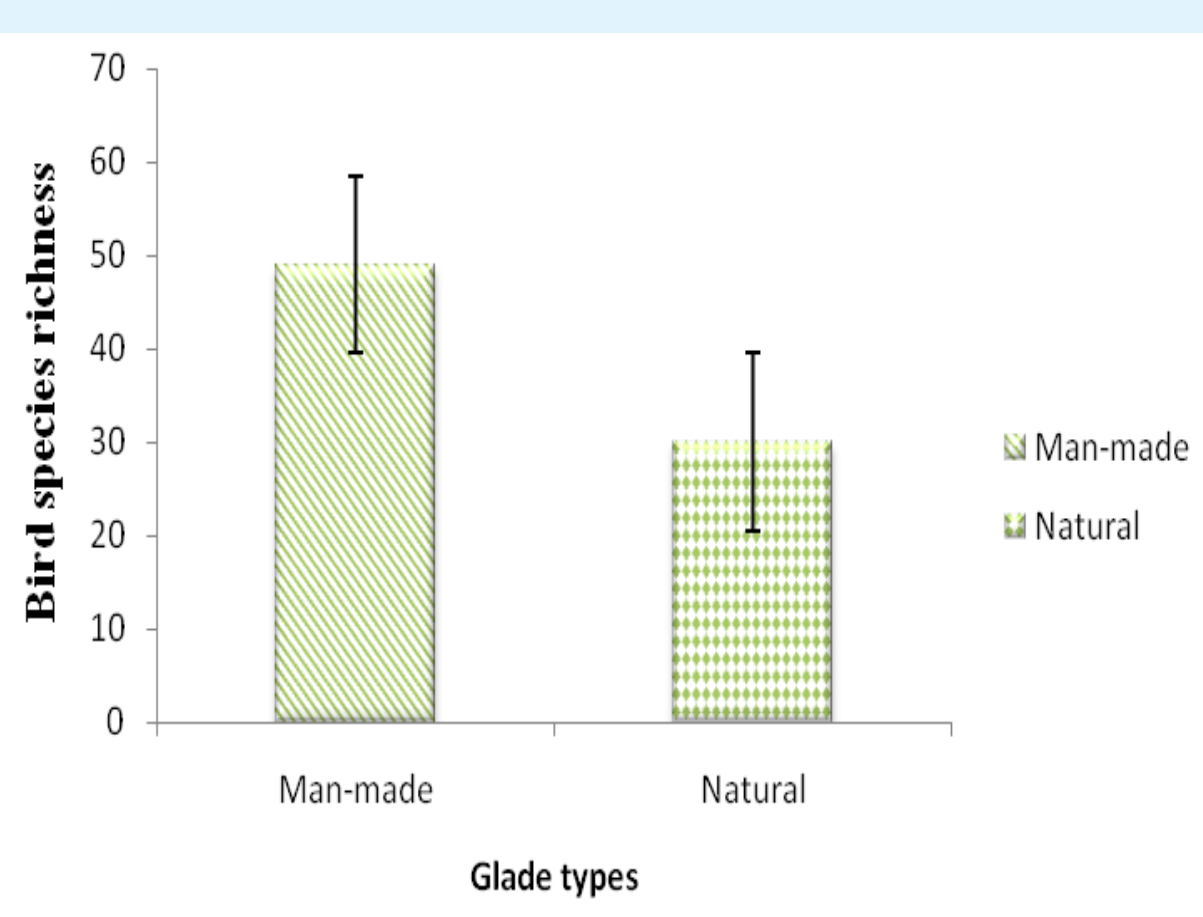

Figure 2: Comparison of bird species richness between man-made glades (49) and natural glades (30).

\section{Bird feeding guilds in man-made and natural glades}

Insectivores were the most dominant feeding guild present in both glade types (man-made $=35 \%$ and natural glade $=46$ ), and the least for Granivores/Insectivores (2\%) in man-made glade and Carnivores/Piscivores/Insectivores (3\%) in natural glade as shown in Table 3.

\begin{tabular}{|c|c|c|}
\hline Feeding Guilds & $\begin{array}{c}\text { Feeding guilds in man-made } \\
\text { glades (\%) }\end{array}$ & $\begin{array}{c}\text { Feeding guilds in natural glades } \\
\text { (\%) }\end{array}$ \\
\hline Carnivores & 6 & 10 \\
\hline Frugivores & 13 & 7 \\
\hline Granivores & 8 & 0 \\
\hline Insectivores & 35 & 0 \\
\hline Nectarivores & 4 & 10 \\
\hline Omnivores & 8 & 7 \\
\hline Carnivore/Insectivores & 10 & 10 \\
\hline Frugivores/Insectivores & 8 & 7 \\
\hline Granivores/Insectivores & 2 & 3 \\
\hline Carnivores/Piscivores/Insectivores & 6 & $\mathbf{1 0 0}$ \\
\hline Total & $\mathbf{1 0 0}$ & \\
\hline
\end{tabular}

Table 3: Feeding guilds of birds observed in man-made $(n=49)$ and natural glades $(n=30)$ in percentages $(\%)$.

\section{Discussion}

Bird population monitoring is essential in wildlife management and provides a more precise estimate of bird population diversity, abundance, densities and richness for comparison with other studies and other sites. Understanding the factors responsible for changes in populations has implications for management strategies. 


\section{Journal of Ecology \& Natural Resources}

The overall study through empirical observation showed that man-made glades hold a significant higher bird species diversity, richness and evenness than natural glades.

\section{Bird species diversity, richness and evenness in man-made and natural glades}

The high bird species diversity, richness and evenness in man-made glades were attributed to the availability of different microhabitats in man-made glades that offered heterogeneous conditions. Habitat heterogeneity increases bird species diversity, richness and evenness. The microhabitats seen in the area were shallow marshes (vernal pools), shrubland, grassland and forest area which offered three dimension microhabitats (lower canopy, middle canopy and higher canopy) [17]. For example, shallow marshes (vernal pools) in man-made glades attracted varieties of water birds, such as Black Smith Lapwing, and Egyptian and Spur Winged Goose and waders, such as Black Headed Heron, Cattle Egret, and Hadada and Sacred Ibis $[17,38]$. Similar to observation reported in other studies, waders prefer shallow marshes (vernal pools) covered with moderate to low grasses for movement, hunting and foraging efficiency [38] (. In addition, habitat heterogeneity fosters high bird species diversity, richness and evenness in man-made glades by permitting a broader range of resources, such as different food items.

Vegetation diversity, structure, cover and open canopy features attracts birds to nest, forage and roost [39]. Different vegetation diversity give an opportunity to bird species to adapt in different feeding habits such as fruit eaters, insect eaters, seed eaters and nectar consumers hence higher species diversity. The high level of vegetation cover in man -made glade was due to the well branched trees, dense bush and shrubs that determine micro-climatic conditions such as increased shade and the amount of litter. Such micro-climatic conditions support an increased bird species activity such as feeding and roosting [40,37]. Also, the dense vegetation provides a diversity of sites for ground and shrub nesters, feeding, suitable roosting and breeding as well as, cover to escape from predators, as reported by $[40,30]$. Also the presence of high structural diversity of vegetation in man-made glades leads to high diversity of food items such as fruits, nectar and seeds hence higher species diversity [17].

\section{Bird feeding guilds in man-made and natural glades}

The bird feeding guilds between man-made and natural glades varied in terms of bird species composition. This was a result, of differences in vegetation cover, structures and floristic composition (Rajpar \& Zakaria, 2011). For example, the presence of fruiting and flowering shrubs, such as Carrisa spinarum and Lantana camara increased high abundance of Insectivores, Frugivores, Omnivores, and nectar-feeding birds, such as bee-eater, bulbuls, barbets, doves, hornbills, and mousebird in both manmade and natural glades [26,38]. Moreover, the shrubs and trees provided a diversity of flowers, and fruits that attracted a wide variety of insects [38]. Fruits, nectar, flowers, seeds and insects were the major food resources for these birds $[26,38,30]$. The bill shape helps to determine the type of food resource exploited by a particular bird species [41]. For example, Sunbirds have decurved bill (probe) that is long and slender for probing flowers for nectar and sometimes feeds on insects; seed eaters like sparrows have short, thick conical bills for cracking seeds; insect eaters like warblers and flycatchers have thin, pointed bills (tweezers); birds of prey, such as hawks and eagles, have sharp, curved bills (shredders) for tearing flesh; ducks have long, flat bills (strainers) that strain small plants and animals from the water; and herons have spear-like bills adapted for feeding on a wide variety of aquatic animals, including fish, reptiles, amphibians, crustaceans, molluscs and aquatic insects $[41,28]$. Furthermore, the presence of wild herbivores, such as buffalos and giraffes, influence the diversity and abundance of Insectivores, such as red and yellow-billed oxpeckers in man-made and natural glades that feed on the ticks attached to these animals [28]. In addition, most insects, such as ticks and flies, are preferred in areas inhabited by these large wild herbivores, such as buffalos [42].

Overall, the results signify that each bird feeding guild group in both man-made glade and natural glade are determined by microhabitat and micro-climate conditions. Microhabitat and micro-climate conditions determined the food resources available to bird species in both glade types [38]. Likewise, the selection of microhabitat and micro-climate condition differs from one bird species to another [38]. 


\section{Journal of Ecology \& Natural Resources}

\section{Limitations of the study}

The weather had a major impact on the results of the study. The activity of the birds is dependent on weather (e.g. rain, cloud cover, temperature and fog). During the study period, there were periods of rainfall and fog which obstructed bird surveys, and also possibly reduced significantly the number of bird species that were detected, counted and recorded [43]. Fog impaired the sighting of birds with binoculars because the binocular optic lens became filled with water drops. Also, fog restricted the observation of bird species to within a short distance.

\section{Conclusion and Recommendation}

In conclusion, bird species diversity, richness and evenness were high in man-made glades. Bird feeding guilds differed from glade to glade, with insectivores being most dominant feeding guild for both glade types. Habitat manipulation and re-clearing of forest invasion for man-made glades should proceed in order to generate these different unique microhabitats that are vital to the conservation of a wide variety of bird species. This study should serve as a basis for future bird population monitoring, because the study was conducted before reclearing the man-made glades of forest invasion.

\section{Acknowledgments}

First of all, I would like to thank almighty God for keeping me alive until now and also to my family for their financial, love and moral support for my studies and conduct this research.

I would like to express my sincere gratitude to my supervisor, Dr. Ladislaus W. Kahana, for his support from the beginning of this research up to the submission of final report through his constructive guidance and advice throughout the study. Heartily I appreciate the sincerity and diligence of his comments and words of motivation and support.

My heartfelt gratitude goes to the followings $\mathrm{Mr}$. Deogratius M. Maige, Erick G. Lutashu, Joachim L. Msenga, Idd M. Kiboga and Senso M. Kwembea for their invaluable help, experiences, and Information sharing during data collection.

I am also Indebted to the College of African Wildlife Management library for their support.
Lastly, I would like to thank all Bachelor Degree in Wildlife Management and Tourism third year for their cooperation and everyone who participated in or contributed to this final research project report.

\section{References}

1. Ricklefs RE (2004) A comprehensive framework for global patterns in biodiversity. Ecol. Lett 7(1): 1-15.

2. Mittelbach GG, Schemske DW, Cornell HV, Allen AP, Brown JM, et al. (2007) Evolution and the latitudinal diversity gradient: speciation, extinction and biogeography. Ecology letters 10(4): 315-31.

3. Linder HP (2008) Plant species radiations: where, when, why? Philos Trans R Soc Lond B Biol Sci 363(1506): 3097-105.

4. Jetz W, Thomas GH, Joy JB, Hartmann K, Mooers AO (2012) The global diversity of birds in space and time. Nature 491(7424): 444-448.

5. Ricklefs RE, Schluter D (1993) Species Diversity in Ecological Communities: Historical and Geographical Perspectives. University of Chicago Press, Journal of Evolutionary Biology 7: 635-636.

6. Millennium Ecosystem Assessment (2005) Ecosystems and human well-being: Synthesis. Island Press, Washington, DC.

7. Hannah L (2012) As Threats to Biodiversity Grow, Can We Save World's Species? .Yale Environment 360.

8. Newton I (2003) The speciation and biogeography of birds. London, Academic Press.

9. Pomeroy DE (1992) Counting Birds. A guide to assessing numbers, biomes and diversity of Afro tropical birds, University of Makerere. Kampala, Uganda.

10. Birdlife International (2013) Birds are found almost everywhere in the world, from the poles to the equator.

11. Rowhani P, Christopher A Lepczyk, Marc A Linderman, Anna M Pidgeon, Volker C. Radeloff, et al. (2008) Variability in Energy Influences Avian Distribution Patterns across the USA. Ecosystems 11(6): 854-867. 
12. Newman K (2010) Rare and endangered birds of Southern Africa [poster]. $86 \mathrm{~cm} \times 59.4 \mathrm{~cm}$. Korck Publisher.Isbn:978062020367.

13. Frost JS, Powell LA (2011) Cedar Infestation Impacts Avian Communities along the Niobrara River Valley, Nebraska. Restoration Ecology 19(4): 529-536.

14. Wetlands International (2010) State of the World's Water birds. (Compiled by Simon Delany, Szabolcs Nagy and Nick Davidson). Wetlands International, Ede, the Netherland.

15. Bond WJ, Woodward FI, Midgley GF (2005) The global distribution of ecosystems in a world without fire. New Phytologist 165(2): 525-538.

16. Nelson PW, Fitzgerald JA, Larson K, McCoy R, Schotz, A, et al. (2013) Central Hardwoods Joint Venture Glade Conservation Assessment for the Interior Highlands and Interior Low Plateaus of the Central Hardwoods Region. Central Hardwoods Joint Venture.

17. Kahana LW, Malan G, Sylvina TJ (2013) Forest bird diversity and edge effects on three glade types at Mount Meru Game Reserve, Tanzania. International Journal of Biodiversity and Conservation 5 (11): 715728.

18. Probasco GE (2007) Bird Habitat-Woody Plant Relations on Missouri Limestone Glade 107-109.

19. Sankaran M, Hanan NP, Scholes RJ, Ratnam J, Augustine DJ, et al. (2005) Determinants of woody cover in African savannas. Nature 438 (7069): 846849 .

20. Liu F, Archer SR, Gelwick F, Bai E, Boutton TW, et al. (2013) Woody Plant Encroachment into Grasslands: Spatial Patterns of Functional Group Distribution and Community Development. PLoS one 8(12): e84364.

21. Ward D, Hoffman MT, Collocott SJ (2014) A century of woody plant encroachment in the dry Kimberley savanna of South Africa. African Journal of Range \& Forage Science, 31(2): 107-121.

22. Murcia C (1995) Edge effects in fragmented forests: implications for conservation. Trends in Eco. Evol 10(2): 58-62.

23. Dunn RR (2004) "Managing the tropical landscape: a comparison of the effects of logging and forest conversion to agriculture on ants, birds, and Lepidoptera," Forest Ecol and Manage 191(1-3): 215224.

24. Maleko DD, Mbassa GN, Maanga WF, Sisya ES (2012) Impacts of Wildlife-Livestock Interactions in and around Arusha National Park, Tanzania. Current Research Journal of Biological Sciences 4(4): 471-476.

25. Galanti V, Loibooki B (2003) Arusha National Park General Management Plan, Tanzania National Park. Department of Planning and Development Projects.

26. Aravind N, Rao D, Ganeshaiah KN, Uma Shaanker R, Poulsen John G (2010) Impact of the invasive plant, Lantana camara, on bird assemblages at Male Mahadeshwara Reserve Forest, South India. Tropical Ecology 51(2S): 325-338.

27. Niemuth ND, Estery ME, Reynolds RE, Leach CL, Meeks WA (2006) Use of wetlands by spring-migrant shorebirds in agricultural landscapes of North Dakota's drift prairie. Wetlands 26(1): 30-39.

28. Stevenson T, Fanshawe J (2004) Field guide of the birds of East Africa: Kenya, Tanzania, Uganda, Rwanda and Burundi). A\& C Black.

29. Sutherland WJ (2000) The Conservation Handbook Research, Management and Policy. Blackwell Science Ltd, London.

30. Zakaria M, Rajpar MN, Sajap AS (2009) Species Diversity and Feeding Guilds of Birds in Paya Indah Wetland Reserve, Peninsular Malaysia. International Journal of Zoological Research 5(3) 86-100.

31. McGinley M (2014) Species diversity. Retrieved from.

32. Magurran AE, McGill BJ (2011) Biological diversity: Frontiers in measurement and assessment. Oxford University Press, Oxford.

33. Hamel PB, Smith WP, Twedt DJ, Woehr Jr, Morris E, et al. (1996) A Land Manager's Guide to Point Counts of Birds in the Southeast.

34. Mulwa RK, Böhning-Gaese K, Schleuning M (2012) High Bird Species Diversity in Structurally Heterogeneous Farmland in Western Kenya. Biotropica 44(6): 801-809.

35. Mammides C, Kadis C, Coulson T (2014) The effects of road networks and habitat heterogeneity on the 
species richness of birds in Natura 2000 sites in Cyprus. Landscape Ecology 30(1) 67-75.

36. James E Hines, Thierry Boulinier, James D. Nichols, John R. Sauer, Kenneth HP, et al. (1999) COMDYN: software to study the dynamics of animal communities using a capture-recaptures approach. Bird Study 46: S209-S217.

37. Kumssa T, Bekele A (2013) Population status, feeding ecology and activity pattern of helmeted guinea fowl (Numidia meleagris) in Abijata-Shalla Lakes National Park. African Journal of Environmental Science and Technology 7(1): 49-55.

38. Rajpar MN, Zakaria M (2011) Bird Species Abundance and Their Correlationship with Microclimate and Habitat Variables at Natural Wetland Reserve, Peninsular Malaysia. International Journal of Zoology 1-18.

39. Mengesha G, Mamo Y, Bekele A (2011) A comparison of terrestrial bird community structure in the undisturbed and disturbed areas of the Abijata Shalla lakes national park, Ethiopia. International Journal of Biodiversity and Conservation 3(9): 389-404.
40. Asokan S, Thiyagesan K, Nagarajan R, Kanakasabai R (2003) Studies on Merops orientalis Latham 1801 with special reference to its population in Mayiladuthurai, Tamil Nadu. J Environ Biol 24(4): 477-482.

41. Sekerciouglu CH (2006) Handbook of the birds of the world. Thesis (PhD), Stanford University, Department of biological sciences, Center for conservation biology, Stanford California, USA.

42. Keesing F, Allan BF, Young TP, Ostfeld RS (2013) Effects of wildlife and cattle on tick abundance in central Kenya. Ecological Applications 23(6): 14101418.

43. Robbins CS (1981) Bird activity levels related to weather.

44. IUCN (1990) Conserving the world's biological diversity. Prepared and published by IUCN Gland, Switzerland, and Washington, D.C. 